\title{
ХАРАКТЕР ТРАНСФОРМАЦІЇ ЗАСОБІВ ПСИХОЛОГІЧНОГО АНАЛІЗУ В УКРАЇНОМОВНИХ І РОСІЙСЬКОМОВНИХ ПЕРЕКЛАДАХ РОМАНУ С. ЛЕМА «СОЛЯРІС»
}

\author{
Кравченко Я. П. \\ кандидат філологічних наук, дочент, \\ доцент кафедри німецької філології і перекладу \\ Запорізький національний університет \\ вул. Жуковського, 66, Запоріжжя, Украӥна \\ orcid.org/0000-0002-1219-4688 \\ yana_kr@yahoo.com
}

\author{
Ключові слова: \\ перекладознавча \\ компаративістика, \\ порівняльне \\ літературознавство, \\ інтерпретачія, герменевтична \\ парадигма перекладу, \\ перекладацуькі трансформації, \\ жанровий канон, концегція \\ особистості.
}

У статті розглянуто специфіку перекладацьких трансформацій засобів художнього психологізму на прикладі перекладів роману С. Лема «Соляріс» українською і російською мовами. Вибір об’єкту аналізу зумовлений розмаїттям форм мистецької рецепції даного твору у вітчизняному культурному просторі і його місцем в каноні масової художньої літератури радянського i пострадянського періодів. Методологічною підставою порівняльного аналізу є сучасна герменевтична парадигма перекладацької діяльності, що ефективно синтезує методи компаративістики і перекладознавства. Важливість перекладознавчого аспекту інтерпретації художнього твору зумовлена його трансдисциплінарною специфікою (поєднанням рис філософського, літературознавчого, лінгвістичного, лінгвокультурологічного різновидів аналізу). Здійснений порівняльний аналіз перекладацької інтерпретації засобів психологізму в романі С. Лема «Соляріс» засвідчує, що способи перекладу мають суттєві відмінності, визначені специфікою розуміння перекладачем концепції особистості головного героя і жанрової специфіки твору. Переклад Г. Гудімової, В. Перельман позбавлений підвищеної емоційності і метафоричності, репрезентує читачеві тип героя-аналітика, філософа i раціоналіста-вченого. Переклад внутрішнього мовлення героя, вибір лексем для характеристики його психологічного стану, дій, мотивації вчинків, предметного оточення орієнтований на мінімальну кількість засобів виразності, що властиво більшою мірою екзистенційній філософській прозі. Переклади Д. Брускіна і Д. Андрухіва орієнтовані на жанровий канон наукової фантастики як різновиду пригодницької літератури, що відобразилося в обраній перекладацькій стратегії. Психологічні характеристики героя більш художньо виразні, емоційні, образно-метафоричні. Зафіксовані відмінності перекладів не вказують на хибну перекладацьку інтерпретацію, а являють собою єдине поле смислів - культурно-історичних, ідеологічних, мовних тощо. 


\title{
THE NATURE OF PSYCHOLOGICAL ANALYSIS TRANSFORMATION MEANS IN UKRAINIAN-LANGUAGE AND RUSSIAN-LANGUAGE TRANSLATIONS OF S. LEM'S NOVEL "SOLARIS"
}

\author{
Kravchenko Ya. P. \\ Candidate of Philological Sciences, \\ Associate Professor at the Department of German Philology and Translation \\ Zaporizhzhia National University \\ Zhukovskoho str., 66, Zaporizhzhia, Ukraine \\ orcid.org/0000-0002-1219-4688 \\ yana_kr@yahoo.com
}

\begin{abstract}
Key words: comparative translation studies, interpretation, hermeneutic paradigm of translation, translation transformations, genre canon, personality concept.
\end{abstract}

\begin{abstract}
The article studies the specificity of translation transformations of literary psychologism means based on the translations of S. Lem's novel "Solaris" into Ukrainian and Russian languages. The choice of the object under analysis is determined by various forms of literary perception of the novel in the national cultural space and its place in the canon of popular literary works of the Soviet and post-Soviet periods. The methodological foundation of the comparative analysis is the modern hermeneutic paradigm of translation activity which efficiently synthesizes the methods of comparative and translation studies. The translation aspect of literary text interpretation becomes significant due to its transdisciplinary specificity (a combination of features typical of philosophical, literary, linguistic, and linguaculturological types of analysis). The accomplished comparative analysis of psychologism means interpretation by the translators of S. Lem's "Solaris" confirms that the methods of translation used have essential differences determined by the specificity of the translator's understanding of the main character's personality concept and the genre peculiarity of the literary work. The translation by G. Gudimova and V. Perelman is deprived of excessive emotionality and metaphoricity as well as presents to the reader the character as an analyst, philosopher, and rational scientist. The translation of the character's inner speech, as well as the choice of vocabulary to characterize his psychological state, actions, motivation for certain behavior, and environment are aimed at the minimum number of expressive means, which is mainly typical of the existential philosophical prose. The translations by D. Bruskin and D. Andrukhiv are targeted at the genre canon of science fiction as a variety of adventure literature, which is reflected in the choice of the translation strategy used. The character's psychological features are more literary expressive, emotional, and figuratively metaphoric. The differences in translations revealed do not indicate that a certain translation interpretation is irrelevant but rather represent an integrated field of meanings - cultural, historical, ideological, religious, linguistic, and other ones.
\end{abstract}

Постановка проблеми. Специфіка смислових трансформацій оригіналу художнього твору при перекладі є актуальною галуззю досліджень в сучасній перекладознавчій компаративістиці, адже переклад розуміється не лише як спосіб взаємодії літературних традицій, а і як можливість осягнути смислову багатогранність оригінального твору. Одна з найважливіших стадій процесу перекладу - стадія інтерпретації, що, за словами Е. Мишкурова, є герменевтичною душею перекладу [6, с. 42]. Будучи варіантом інтерпретації, переклад трансформує i адаптує художній світ твору в комплекс світоглядних характеристик, що сприймаються реципієнтом-читачем в контексті власної картини світу - національної психології, традицій, мови, ідеології, релігії, цінностей тощо.

У цьому контексті актуальним є питання про існування різних варіантів перекладу одного твору в межах певної національної літератури. У роботах С. Голубцова [1], Л. Калабекової [2], Є. Шерстневої [7] утверджується думка про те, що переклади одного твору можуть розглядатися в сукупності, тобто як цілісний філологічний об'єкт, своєрідний гіпертекст. Об'єктивне 
відображення оригіналу (особливо, якщо це твір, що має культурно-історичну цінність) досягається через кілька перекладів, які доповнюють один одного, розкривають різні аспекти оригіналу. С. Голубцов зазначає: «У тому випадку, коли твір налічує значну кількість перекладів, розгляд цього твору в широкому філологічному контексті наявних транспозицій відкриває нові перспективи у вивченні художньої літератури, а також в практиці перекладу» [1, с. 29]. Отже, аналіз знакових для культури певної доби літературних творів потребує вивчення їхніх перекладацьких варіантів. Це, вочевидь, може надати об'єктивні дані про способи входження тексту в іншомовну культуру і про специфічні трансформації смислу, що відбулися в процесі адаптації в іншомовному середовищі.

Мета і завдання статті. Метою даної розвідки $є$ аналіз перекладацьких трансформацій форм художнього психологізму, репрезентованих в російськомовних та україномовних перекладах роману С. Лема «Соляріс».

Предмет i об'єкт дослідження. Об'єктом дослідження $\epsilon$ переклади роману С. Лема «Соляріс» російською мовою, виконані Д. Брускіним (1963р.) і Г. Гудімовою, В. Перельман (1976 р.) та переклад українською мовою, виконаний Д. Андрухівом (1987). Предметом дослідження $\epsilon$ перекладацькі трансформації засобів психологічного аналізу.

Виклад основного матеріалу дослідження. У вітчизняному культурному просторі останньої третини XX ст. роман польського письменника С. Лема «Соляріс» набув статусу культового твору, адже з його появою радянський масовий читач, звиклий до традицій соціалістичного реалізму, долучався до проблеми підсвідомого і його виявів у житті людини. Роман не лише започаткував потужну традицію наукової фантастики, а і дав початок осмисленню низки світоглядно-ціннісних аспектів буття, а саме: природи Бога як Іншого, меж наукового знання, свободи i волі людини тощо. Переклад став одним з факторів, що забезпечив книзі іiї небачену популярність, різні форми мистецької і наукової рецепції, а також місце в каноні жанру наукової фантастики.

Переклади окремих глав російською 3'явилися вже у 1961 р., невдовзі після публікації твору польською (автор перекладу - С. Ковалевський). У 1962 р. вийшов переклад Д. Брускіна, узгоджений 3 автором і згодом ним авторизований. Це найбільш авторитетний переклад, він друкувався 35 разів і продовжує виходити зараз. Однак вже у 1970-ті з'являється думка, що переклад Д. Брускіна не цілком передає повноту сенсу оригіналу: суворе редагування піддало текст скороченню (кілька сторінок про порівняння розумного Океану з Богом), що істотно впливає на зміст роману.
У 1976 р. роман був наново перекладений (в повному обсязі і без скорочень) Г. Гудімовою та В. Перельман і опублікований у збірці «Вибране» (С. Лем. Москва, 1976 р.). Переклад витримав шість видань, проте вважається таким, що не зберігає мовно-стилістичні особливості оригіналу.

Дослідники неодноразово відзначали відмінності в російськомовних варіантах перекладу роману. Так, у перекладі В. Ковалевського планета і океан називаються «Соларіс» - це слова жіночого роду відповідно до польського оригіналу (жіночий рід ім'я океану має і в перекладі Г. Гудімової і В. Перельман). У перекладі Д. Брускіна використовується написання «Солярис», при цьому це ім'я чоловічого роду (ймовірно, для узгодження зі словом «океан»). У цій формі слово найбільш міцно увійшло в російську мову. В оригіналі назва «Соляріс» жіночого роду. У польському варіанті це виразна особливість, тому що там, як і в українській мові, жіночі імена такого роду не відмінюються: «поверхню Соляріс», «тут, на Соляріс» тощо. У перекладі Г. Гудімової і В. Перельман перекладачі пишуть слово «Океан» 3 великої літери, це слово стає власним ім'ям, тобто розумний Океан і планета Соляріс - це різні істоти, хоча у Лема такого розмежування немає.

У 1987 р. був опублікований ліцензований україномовний переклад Д. Андрухіва (Київ: Молодь, 1987), виконаний ним набагато раніше $i$ виданий вперше у 1970-ті без дозволу С. Лема у видавництві «Дніпро». У двотисячні роки переклад Д. Андрухіва тричі перевидавався у видавництві «Навчальна книга-Богдан» $(2002,2017)$ i «Кальварія» (2017). Переклад отримав схвальні оцінки і сьогодні $є$ затребуваним серед українських читачів, про що свідчать тиражі зазначених видань.

Отже, i україномовний, i російськомовний читач має можливість обрати будь-який з перекладів. Кожен $з$ перекладів, вочевидь, відповідає усталеним критеріям оцінки перекладу. Це такі критерії: збереження художніх образів, ідеї оригіналу; передача пропорцій оригіналу на образному рівні; тенденція до точності перекладу оригіналу мовою перекладача; збереження авторської позиції; співвідношення перекладу і оригіналу на стилістичному рівні; збереження багатозначності першотвору, його підтексту.

Попри високу художню якість перекладу, залишається відкритим питання про відмінності у репрезентації перекладачами авторської концепції особистості. «Соляріс» - глибоко філософський і психологічний твір. Попри науково-фантастичну фабулу, особистісно-психологічна складова тут домінує, що знаходить підтвердження у проблематиці численних діалогів і сюжетних колізіях: «Людина вирушила на зустріч $з$ іншими світами, 
іншими цивілізаціями, не пізнавши до кінця закамарків, глухих кутів, глибоких колодязів, міцно забарикадованих дверей власної душі» [5, с. 177]. Цей роман написаний про страхи, потаємні бажання, нав'язливі ідеї людей. Тут ідеться про дію на людину факторів підсвідомості, природу сновидінь, марень тощо. Психологізація визначена і оповідною стратегією твору - це Я-наратив iз притаманним йому суб' єктивізмом, домінуванням саморефлексії і самохарактеристики. Форми художнього психологізму є ключем до розуміння авторської концепції людини.

В аспекті передачі форм психологічного аналізу розглянемо особливості перекладу глави роману «Сарторіус», яка є психологічно переломною, оскільки саме тут відбувається усвідомлення Кельвіном масштабів впливу Соляріс на свідомість і поведінку людини.

Одним 3 психологічно напружених моментів $є$ знахідка Кельвіном мертвого Гібаряна i подальше відтворення фізичних i психо-емоційних реакцій персонажа. Фіксація побаченого в свідомості героя в різних перекладах відтворюється 3 певними відмінностями. У перекладі Г. Гудімової, В. Перельман читаємо: «В глубине сводчатый потолок снижался. Там висела плотная, искрящаяся от изморози штора. Я отогнул ее край. На решетчатом алюминиевом столе лежало что-то большое, продолговатое, покрытое серой тканью (у перекладі Д. Брускіна - «покрытый серой тканью большой продолговатый предмет» [4, с. 47]). Приподняв ее, я увидел застьвиее лицо Гибаряна (у перекладі Д. Брускіна - «искаженное лицо» [4, с. 47]). Черные волосы с седой прядкой на лбу были гладко причесаны (у перекладі Д. Брускіна - «гладко прилегали к черепу» [4, с. 47]), кадык торчал, словно шея была сломана (у перекладі Д. Брускіна - «переламывая линию шеи» [4, с. 47], у перекладі Д. Андрухіва «переламуючи лінію шиї, високо стирчав борлак» $[5$, c. 51])... Я так замерз, что с трудом сдерживал дрожь (у перекладі Д. Брускіна - «Холод пронизывал меня, я с трудом заставлял себя не cmучать зубами» [4, с. 48], у перекладі Д. Андрухіва - «Мене пробирав такий холод, що я ледве стримував дрож» [5, с. 51]). Не выпуская из руки ткани (у перекладі Д. Брускіна - «не выпуская савана» $[4$, с. 48]), я другой рукой коснулся щеки Гибаряна» [3, с. 55]. Виділені нами відмінності у перекладі Д. Брускіна вказують на прагнення не лише зафіксувати відчай, жах і нерозуміння того, що відбувається, а й максимально загострити ефект від побаченого. Переклади Д. Брускіна і Д. Андрухіва відрізняє підвищений ступінь емоційності за рахунок використаних лексем «череп», «саван», тоді як переклад Г. Гудімової, В. Перельман більш відсторонений, об'єктивно фіксує побачене і відчуте героєм, тут присутня лексика більш нейтральної семантики. Зазначимо, що остання перекладацька стратегія у репрезентації поведінки персонажа виправдана об'єктивними авторськими характеристиками героя, адже за фахом він науковець, психолог. У своїх реакціях Кельвін не виходить за межі фіксації і раціонального аналізу побаченого.

Подібному ефекту сприяє відчутно більший ступінь натуралістичності описів у перекладі Г. Гудімової: «...Это были пальцы ног, выпукльле подушечки больших пальцев чуть расставлены (у перекладі Д. Брускіна - «яйцеобразные подушечки пальцев были слегка раздвинуты» [4, с. 48]). Под смятой тканью распласталась негритянка» (у перекладі Д. Брускіна - «под мятым пологом савана лежала негритянка» [4, с. 47], у перекладі Д. Андрухіва - «під зім'ятим краєм савана розпласталася негритянка» [5, с. 51]). Використаний Д. Брускіним і Д. Андрухівом іменник «саван», на відміну від нейтральної лексеми «тканина», додає драматизму ситуації, оскільки викликає цілком конкретні асоціації із вбранням покійника і $є$ емоційно забарвленим.

Під час відтворення відчуттів і передачі внутрішнього мовлення Кельвіна у вигляді потоку свідомості Д. Брускін частіше обирає особовий займенник «я» в називному відмінку, що, очевидно, має на меті надати оповіді більш особистісний характер. Натомість у перекладі Г. Гудімової, В. Перельман використано родовий або давальний відмінок - «мене» «мені»: «... Трап вывел меня в зал космодрома... Меня будто избили (у перекладі Д. Брускіна - «я был совершенно разбит» $[4$, с. 48]). Что со мной творится? Я был раздавлен, мысли лавиной катились к пропасти» (у перекладі Д. Брускіна - «мысли сползали в какую-то пропасть» [4, с. 48]). Інакше читаємо у перекладі Д. Андрухіва: «По моєму тілу наче пройшов важкий коток. Я не знав, що зі мною діється. Був розчавлений» [5, с. 52].

Внутрішній монолог Кріса продовжує риторичне запитання: «Зачем идти к Снауту или Сарториусу?» - переклад Г. Гудімової, В. Перельман [3, с. 56]. У перекладі Д. Брускіна риторичне питання замінюється твердженням: «Мне незачем было идти к Снауту или Сарториусу» [4, с. 49]). Далі у перекладі Г. Гудімової ще одне риторичне запитання підсилює враження розгубленості героя: «Кто сможет свести воедино все то, что я до сих пор пережил, увидел и ощутил? (у перекладі Д. Брускіна знову утвердження - «я не представлял себе, чтобы кто-нибудь мог сложить в единое целое» [4, с. 49]) Безумие - вот единственное объяснение, бегство, избавление [3, с. 56]» (у перекладі Д. Брускіна - «единственным спасением был диагноз - сумасшествие» [4, с. 49], 
у перекладі Д. Андрухіва - «С диним порятунком, утечею, поясненням був діагноз - божевілля» [5, с. 52]). Використане у перекладах Д. Брускіна і Д. Андрухіва слово «діагноз» надає самоаналізу Кельвіна науково-аналітичного характеру, що відповідає логіці характеру персонажа-вченого, для якого саморефлексія $є$ звичним способом самопізнання.

Відмінності у перекладі засобів психологічного аналізу фіксуємо у внутрішньому монолозі героя й надалі: «...Как знать, может, я все еще на борту «Прометея» и у меня острый приступ душевной болезни?» [3, с. 57]. Аналогічно читаємо у перекладі Д. Андрухіва: «Хтозна, чи не перебуваю я ще й досі на борту «Прометея», уражений гострим нападом душевної хвороби» [5, с. 52] (у перекладі Д. Брускіна - «пораженный внезапнылм приступом мозгового заболевания») [4, с. 49]. Очевидно, що словосполучення «мозкове захворювання» не наділене таким широким спектром читацьких асоціацій, як словосполучення «душевна хвороба», що має тривалу історію мистецької поетизації. Ймовірно, переклад Д. Брускіна прагне уникнути цього асоціативного ряду i остаточно сформувати уявлення про персонажа-аналітика. Далі у перекладі Г. Гудімової читаємо: «Неужели все пережитое порождено моим возбужденным мозгом?» [3, с. 57] (у перекладі Д. Брускіна - «моего разгоряченного воображения» [4, с. 49], у перекладі Д. Андрухіва - «тільки витвір моєї збудженої уяви» [5, с. 52]). Г. Гудімова уникає слова «уява», надаючи перевагу словосполученню «збуджений мозок». Виникає смислова опозиція «уява - мозок», складові частини якої формують протилежні читацькі уявлення. Уява асоціюється із фантазією і сферою емоцій, а збудження мозку прочитується як клінічний діагноз.

Далі спостерігаємо фіксацію логічно вибудованого, майже повністю позбавленого емоційності внутрішнього мовлення Кельвіна. У перекладі Г. Гудімової читаємо: «...Итак, нужно было прежде всего провести какой-то продуманный, логичный эксперимент над самим собой, который показал бы мне, действительно ли я сошел с ума и стал жертвой собственного бреда» [3, с. 57] (у перекладі Д. Брускіна: «Необходимо было, следовательно, провести прежде всего какой-то логично продуманный эксперимент над самим собой - experimentum crucis, который показал бы мне, действительно ли я свихнулся и являюсь жертвой бредовых видений...» [4, с. 49], у перекладі Д. Андрухіва: «Отже, треба було передусім провести якийсь логічно продуманий експеримент над самим собою, experimentum crucis, котрий переконливо довів би мені, чи я справді схибнувся і став жертвою власного божевілля» [5, с. 53]). Зауважимо використання у перекладах Д. Брус- кіна і Д. Андрухіва латинського аналога використаного словосполучення «вирішальне випробування», що, вочевидь, має підсилити уявлення про здоровий глузд героя і аналітичну домінанту його характеру. Г. Гудімова і В. Перельман надають перевагу словосполученню «сошел с ума» замість використаних Д. Брускіним і Д. Андрухівом розмовних лексем «свихнулся», «схибнувся».

Оповідь від першої особи дозволяє не лише відтворювати внутрішнє мовлення героя, а і фіксувати деталі речового оточення: «Я размышлял об этом, рассматривая металлическую опору несущих конструкций космодрома». В перекладі Д. Брускіна читаємо: «Так я размышлял, присматриваясь к металлическому кронштейну, который поддерживал несущую конструкцию ракетодрома» [4, с. 49]. ...А можно ли придумать ключевое испытание?», у перекладі Д. Брускіна - «этот ключевой эксперимент» $[4$, с. 50], у перекладі Д. Андрухіва - «вирішальне випробування» [5, с. 53]. Іменник «опора», використаний Г. Гудімовою, має абсолютно нейтральне стилістичне забарвлення, тоді як слово «кронштейн» узяте 3 розряду інженерно-технічної лексики і позбавлене можливості широкого вживання. Також відзначимо використання різних іменників - «випробування» $\mathrm{i}$ «експеримент». Перший має дуже широкий спектр асоціацій, які, проте, здаються недоречними в перекладі Д. Брускіна, тому перевага віддається другому - більш конкретному.

У деяких випадках перекладачі вважають за краще не підбирати синоніми, а взагалі опускати деякі лексеми. Наприклад, у перекладі Г. Гудімової читаємо: «...Казалось, мне уже не вырваться из заколдованного круга безумия (у перекладі Д. Брускіна: «мне уже казалось, что, попав в этот замкнутый круг, я не сумею из него выбраться» $[4$, с. 50]), ведь можно мыслить только мозгом, нельзя очутиться вне самого себя, чтобы проверить, нормальны ли процессы, протекающие в организме» [3, с. 57]. В українському перекладі читаємо: «потрапивши в це зачароване коло» [5, с. 54]. Як бачимо, Д. Брускін і Д. Андрухів не використовують слово «божевілля», залишаючи лише словосполучення «замкнене коло». Герой не кваліфікує свій стан як божевілля.

Наступний епізод відтворює перехід від напруженого внутрішнього монологу до активного руху. У перекладі Г. Гудімової, В. Перельман читаємо: «Я вскочил и побежал на радиостанцию. Там никого не было. Мимоходом я взглянул на электрические стенные часы. Было около четырех часов ночи по условному времени Станции, за стенами занимался красный рассвет. Включив дальнюю радиосвязь и дожидаясь, пока она наладится, я еще раз продумал ход эксперимента» [3, с. 57]. У перекладі Д. Брускіна читаємо: «Я вскочил 
и помчался прямо на радиостанцию. Она была nуста. Мимоходом я бросил взгляд на стенные электрические часы. Было около четырех часов ночи, условной ночи Станции, снаружи царил красный рассвет... Я быстро включил аппаратуру радиосвязи и, ожидая, пока нагреются лампы, еще раз мысленно повторил каждый этап эксперимента» [4, с. 51]. Різниця у перекладі ключових слів досить виразна. Переклад Д. Брускіна прагне передати внутрішню динаміку дій персонажа, натомість переклад Г. Гудімової більш сконцентрований на відтворенні зовнішніх факторів.

Істотні відмінності у сприйнятті героєм оточуючого простору зумовлені тим, що у перекладі Г. Гудімової, В. Перельман і Д. Андрухіва Соляріс жіночого роду, а в перекладі Д. Брускіна - чоловічого. Наприклад: «Сателлоид испытывает весьма сложные пертурбации под влиянием гравитационного поля Солярис, ее обоих солнц, вращающихся относительно друг друга, а также местных изменений притяжения, вызываемых Океаном» [3, с. 58]. У перекладі Д. Брускіна читаємо: «Не точно, потому что сателлоид подвержен очень сложным пертурбациям, вызванным влиянием гравитационных сил Соляриса, его обоих, кружащих друг около друга солнц, а также локальных изменений притяжения, создаваемых океаном» [4, с. 51]. Фемінність Соляріс формує читацьке уявлення про неї як про праматір, що все народжує, водночас маскулінна подоба створює протилежне ставлення - виклику, суперництва, ворожості.

Завершення епізоду показове в аспекті особливостей передачі психологічного стану героя, оскільки відбувається остаточне самовизначення Кріса щодо пережитого випробування. У перекладі Г. Гудімової читаємо: «...У меня дрожали руки, когда я вынимал из ящика телеграфную ленту. Оба ряда цифр совпадали, как я и предполагал, до четвертого знака включительно. Расхождения появлялись только в пятом. Я не сошел с ума. Последняя надежда исчезла» [3, с. 58]. У перекладі Д. Брускіна читаємо: «Последний лучик надежды угас» [4, с. 52]. У перекладі Д. Андрухіва бачимо: «Останній промінець надіï згас» [5, с. 56]. Фінальна фраза героя у перекладі Д. Брускіна і Д. Андрухіва представлена образно-метафорично - «згаслий промінь надії», натомість у перекладі Г. Гудімової - максимально нейтрально, тобто як логічна фіксація факту.

Висновки і перспективи подальших розробок. Отже, здійснений аналіз засвідчив відмінності у способах передачі засобів психологізму в романі С. Лема. Репрезентовані перекладачами варіанти відтворення внутрішніх переживань демонструють специфічні трансформації смислу, що відбулися в процесі адаптації в іншомовному середовищі. Перекладач-інтерпретатор підпоряд- ковує авторські форми психологічного аналізу власній концепції героя. Так, уявлення про героя-аналітика зумовлює вибір частини специфічних лексичних засобів у перекладі Г. Гудімової, В. Перельман. Переклад внутрішнього мовлення героя, вибір лексем для характеристики його психологічного стану, дій, мотивації вчинків, предметного оточення орієнтований на мінімальну кількість засобів виразності, що властиво більшою мірою екзистенційній філософській прозі. Переклади Д. Брускіна і Д. Андрухіва орієнтовані на жанровий канон наукової фантастики як різновиду пригодницької літератури, що відобразилося в обраній перекладацькій стратегії. Психологічні характеристики героя більш художньо виразні, емоційні, образно-метафоричні. Переклади Д. Брускіна і Д. Андрухіва в плані вибору аналогів демонструють прихильність до іншої концепції особистості героя - динамічного, активного шукача пригод.

Незважаючи на зафіксовані відмінності перекладів, вони існують не незалежно один від одного, тобто вони пов'язані між собою і оригіналом і являють собою єдине поле смислів культурно-історичних, ідеологічних, релігійних, мовних тощо. Порівняння перекладів створює уявлення про об'ємний текст, де кожен переклад презентує певну грань оригіналу, призводить до збагачення смислів, допомагає встановити ціннісну домінанту твору, дозволяє осягнути художній світ автора. Завдяки трансформаціям образу в перекладі відбувається настанова на аналіз і подальше спілкування з текстом. Надалі видається доцільним застосувати при зіставленні даних перекладів методологію гендерного аналізу, адже розбіжності виявилися між чоловічим і жіночим варіантом перекладацького бачення оригіналу, що видається вельми цікавим 3 точки зору вираження різниці світосприйняття.

\section{ЛITЕРАТУРА}

1. Голубцов С.А. Экологический подход к анализу проблемы переводческой множественности. Вестник Адыгейского государственного университета. Серия «Филология и искусствоведение». 2009. Вып. 1 (113). C. 27-34. URL: https://cyberleninka.ru/article/n/ ekologicheskiy-podhod-k-analizu-problemyperevodcheskoy-mnozhestvennosti (дата звернення: 06.08.2021).

2. Калабекова Л.Т. Практическое переводоведение на службе компаративных разысканий. Современные исследования сочиальных проблем. 2014. 12 (44). URL: https://cyberleninka.ru/ article/n/prakticheskoe-perevodovedenie-nasluzhbe-komparativnyh-razyskaniy (дата звернення: 07.08.2021). 
3. Лем С. Солярис. Магелланово облако / пер. Г. Гудимовой, В. Перельман. Москва : Радуга, 1987. C. 19-177.

4. Лем С. Солярис. Непобедимый. Звездные дневники Ийона Тихого / пер. Д. Брускина. Москва : Правда, 1988. С. 3-187.

5. Лем С. Соляріс / пер. Д. Андрухів. Тернопіль : Навчальна книга-Богдан, 2017. 224 с.

6. Мишкуров Э.Н. Герменевтико-переводческий методологический стандарт в зеркале трансдисциплинарности. Вестник Московского университета. Серия «Теория перевода». 2018. № 1. C. 41-52. URL: https:// cyberleninka.ru/article/n/germenevtikoperevodcheskiy-metodologicheskiy-standartv-zerkale-transdistsiplinarnosti-chast-iiiinterpretatsiya (дата звернення: 09.08.2021).

7. Шерстнева Е.С. Переводная множественность как категория переводоведения: история, статус, тенденции. Известия Российского государственного педагогического университета им. А.И. Гериена. 2008. № 2. C. 77-86. URL: https://cyberleninka.ru/article/n/ perevodnaya-mnozhestvennost-kak-kategoriyaperevodovedeniya-istoriya-status-tendentsii (дата звернення: 10.08. 2021).

\section{REFERENCES}

1. Golubtsov S. A. (2009). Ekologicheskiy podkhod $\mathrm{k}$ analizu problemy perevodcheskoy mnozhestvennosti [An ecological approach to the analysis of the problem of translation plurality]. Vestnik Adygeyskogo gosudarstvennogo universiteta. Seriia 2: Filologiya $i$ iskusstvovedeniye, vol. 1 (113), pp. 27-34. URL: https:// cyberleninka.ru/article/n/ekologicheskiypodhod-k-analizu-problemy-perevodcheskoymnozhestvennosti (accessed on 06.08.2021). [in Russian].

2. Kalabekova L. T. (2014). Prakticheskoye perevodovedeniye na sluzhbe komparativnykh razyskaniy [Practical translation studies at the service of comparative researches]. Sovremennyye issledovaniya sotsial'nykh problem, no. 12 (44). URL: https:// cyberleninka.ru/article/n/prakticheskoe-perevodo vedenie-na-sluzhbe-komparativnyh-razyskaniy (accessed on 07.08.2021). [in Russian].

3. Lem S. (1987). Solyaris. Magellanovo oblako [Solaris. The Magellanic Cloud]. Translated by G. Gudimova, V. Perel'man. Moskva : Raduga. [in Russian].

4. Lem S. (1988). Solyaris. Nepobedimyy. Zvezdnyye dnevniki Iyona Tikhogo [Solaris. The Invincible. The Star Diaries: Further Reminiscences of Ijon Tichy]. Translated by D. Bruskin. Moskva : Pravda. [in Russian].

5. Lem S. (2017). Solyarís [Solaris]. Translated by. D. Andrukhív. Ternopíl' : Navchal'na kniga Bogdan. [in Ukrainian].

6. Mishkurov E.N. (2018) Germenevtikoperevodcheskiy metodologicheskiy standart $\mathrm{v}$ zerkale transdistsiplinarnosti [Hermeneutical methodological standard of translation in the mirror of transdisciplinarity]. Vestnik Moskovskogo universiteta. Ser. 22. Teoriya perevoda, vol. 1, pp. 41-52. URL: https://cyberleninka. $\mathrm{ru} /$ article/n/germenevtiko-perevodcheskiymetodologicheskiy-standart-v-zerkaletransdistsiplinarnosti-chast-iii-interpretatsiya (accessed on 09.08.2021). [in Russian].

7. Sherstneva Ye.S. (2008). Perevodnaya mnozhestvennost' kak kategoriya perevodovedeniya: istoriya, status, tendentsii [Translational plurality as a category of translation studies: history, status, trends]. Izvestiya Rossiyskogo gosudarstvennogo pedagogicheskogo universiteta im. A.I. Gertsena, no. 2, pp. 77-86. URL: https://cyberleninka.ru/article/n/perevodnayamnozhestvennost-kak-kategoriya-perevodo vedeniya-istoriya-status-tendentsii (accessed on 09.08.2021). [in Russian]. 